\title{
Biological activity of glycopolymers from Basidiomycetes mushrooms
}

\author{
E.N. Polishchuk, A.G. Kovalenko
}

D.K. Zabolotny Institute of Microbiology and Virology, NAS of Ukraine

154, Zabolotny Str., Kyiv, 03680, Ukraine

polesua@ukr.net

This article gives an overview of the literature data on the biological activity of glycopolymers separated
from cultural liquid, fruit body and mycelia of Basidiomycetes mushroom. The structure and properties of
mushrooms polysaccharides were considered as well as the dependence of their biological activity on the
physical and chemical properties. A possibility of using the preparations based on the mushrooms
polysaccharides for plant protection as well as for therapy and prophylactics of human and animal diseases
was discussed.

Keywords: Basidiomycetes, polysaccharides of mushrooms, structure of Basidiomycetes glycans, chemical and biological properties of Basidiomycetes glycans.

Introduction. Higher Basidiomycetes mushrooms have been used in folk medicine all over the world. They are especially popular in oriental folk medicine. In the early hours of Yuan Dynasty in China (1280-1368) people already knew the healing properties of mushrooms, which were considered to be important treating means, and the images of their fruit bodies are found in literature, masterpieces, in the form of decorations, etc. Curative features of Basidiomycetes mushrooms are also mentioned in ancient literature of Europe and North America, where they are called artistic wood knots [1]. However, investigation on pharmacological and medical features of Basiodiomycetes has

(C) Institute of Molecular Biology and Genetics NAS of Ukraine, 2009 started only recently [2]. The researchers have proven that Basiodiomycetes mushrooms are an endless source of substances with curative features related to numerous diseases [3]. In recent years this information has triggered interest in searching for biologically active components of Basidiomycetes mushrooms and their study, as well as creation of food additives and medical preparations on the basis of fruit bodies and the products of mushroom metabolism. In China 270 mushroom species with possible medical application are registered and more than 100 of them are used in traditional medicine [4]. The analysis of literature data evidences to the fact that today most researches are conducted with Basidiomycetes mushrooms of Auricularia, Flamulina, Ganoderma, Grifola, 
Hericium, Lentinus (Lentinula), Pleurotus, Trametes, Coprinus, Laetiporus, Panus, Shizophyllum and Tremella genera.

Substances, extracted from mushrooms and their cultural liquids, were used as the basis of preparations, widely used as adaptogens and immunogens [5]. It was also revealed that mushrooms are capable of regulating (stabilizing) the immune system, supporting homeostasis, treating and preventing tumours and cardiac diseases, stabilizing cholesterol level in blood, preventing thrombi formation, and regulating blood pressure [6]. While studying the chemical nature of functionally active components, obtained from fruit bodies of Basidiomycetes, the authors of [7] discovered that these substances contain polysaccharides. In the further work they isolated the following preparations: krestin - from mycelium of Trametes versicolor, lentinan from fruit bodies of Lentinus edodes, and schizophyllan - from metabolism products of Schizophyllum commune. Besides, active protein components were isolated from fruit bodies and mycelia of mushrooms - poricyn from Poria corticola and mucoproteins (calvacyn) from Calvacia gigantean $[6,8]$.

Biologically active carbohydrate-containing polymers are different for different mushrooms species. The strains of the same Basidiomycetes species produce [the] combinations with different structural and functional features. For instance, proteoglycan krestin, isolated from SM-101 strain of T. versicolor in Japan, and the one from CoV-1 strain of the same species in China, have different protein molecules, bound to polysaccharide [8].

The aim of the current work is to analyze the literature data, related to the structural and functional variety of carbohydrate-containing biopolymers (glycans, glycoproteins, proteoglycans), produced by Basidiomycetes.

The chemical structure and biological activity of glycans of Basidiomycetes mushrooms. As for chemical structure the polysaccharides of mushrooms are mainly presented by glycans with different types of glicosidic linkage. Basically glucose has $\beta-(1 \rightarrow 3)$ or $\beta$ - $(1 \rightarrow 4)$ links or sequences of $\beta-(1 \rightarrow 3)-,(1 \rightarrow 4)$-links with $\beta$-(1 $1 \rightarrow 6)$-link in the main chain. There are true heteroglycans as well as glycoproteins, containing carbohydrate and protein components. The side chains of heteropolysaccharides are usually linked to the main chain via $(1 \rightarrow 6)$-linkage [9].

It was revealed that antitumour activity is mostly inherent in $\beta$-D-glucans - linear polymers, monomers of which are glucose or other D-monosaccharides. The glycans were classified depending on the type of main structural unit of the polymer. For instance, the structural units of galactans, fucans, xylans, and mannans are galactose, fucose, xylose, and mannose, respectively $[9,10]$.

Biologically active $\beta$-D-glucan has three-dimensional, dexiotropic spatial structure. Polysaccharides with similar antitumour and immunostimulating features, isolated from fruit bodies or mycelia of mushrooms, may differ in structure, chemical composition, and physical parameters [11]. Their activity may depend on the size, form, and degree of molecule branching, water solubility, etc. Biopolymers possess antitumour features if their molecules are linked with $\beta-(1 \rightarrow 3)$ links in the main chain, and with $\beta$ - $(1 \rightarrow 6)$-links in the side chains. $\beta$-glycans with prevailing $(1 \rightarrow 6)$-links in the main chain are characterized by a lower activity. However, it should be mentioned that high molecular mass glycans are more active than glycans with low molecular mass $[12,13]$. Besides, higher antitumour activity is inherent to polysaccharides, isolated from fruit bodies of mushrooms, rather than to those from mycelia. It may also depend on the composition of nutrient medium and cultivation conditions of the latter.

Antitumour features were revealed for the compounds with somewhat different structure, in particular, for hetero- $\beta$-glucans, $\beta$-glycoproteins, $\alpha$-mano- $\beta$-glucans, $\alpha$-glycoproteins, and protein complexes with heteroglucans [14].

The presence of a tertiary structure in [a] three-chain molecule of mushroom $\beta$ - $(1 \rightarrow 3)$-glycans is a necessary condition for immunomodulating and other biological and pharmacological features of macromolecules, for instance, for the impact on nitrogen-acid synthesis of macrophages and activation of G-factor. For example, when macromolecules of lentinan are denaturated to the primary structure using dimethyl sulfoxide, urine, or $\mathrm{NaOH}$, its immunostimulating features are lost, and its antitumour properties decreased in accordance to the denaturation degree [15]. It testifies to the fact that 
immunomodulating activity depends on the presence of a tertiary structure and hydrophilic groups on the molecule surface rather than on the order of monosaccharides in the carbohydrate chain.

The chemical structure of polysaccharides, isolated from fruit bodies and mycelia of $L$. edodes (lentinan) [16] and S. commune (schizophyllan), was mainly investigated. The qualitative analysis of polysaccharides shows that they contain glucose, galactose, and mannose, and the glycans, glucose of which is linked via $(1 \rightarrow 3)$ - or $(1 \rightarrow 4)$-glycosidic linkage, are characteristics of their structures. For instance, lentinan of $950-1050 \mathrm{kDa}$, is presented by $\beta-1$, 3-D-glycan with branching structure. After every five glucose residues in $\mathrm{C}_{6}$ position, two glucopiranose residues, linked via $\beta-1,6$-glucoside bond, deviate from the main chain, [16]. Some side chains are presented by single glucose residues in $\mathrm{C}_{6}$ position [18].

The results, proving correlation between antitumour activity and configuration of three-chain structure of glycans, were also obtained for schizophyllan. The polysaccharide studied were in the range of $5 \cdot 10^{3} \cdot-1.3 \cdot 10^{5} \mathrm{Da}$. The investigation on their ability to inhibit development of Sarcoma 180 in mice revealed that high antitumour activity is inherent to the samples with molecular mass $9 \cdot 10^{4} \mathrm{Da}$. The preparations with molecular mass lower $10^{4} \mathrm{Da}$ inhibit tumour development less effectively or do not inhibit it at all. The investigation of schizophyllan conformation in water solution showed that the molecules with molecular mass over $9 \cdot 10^{4} \mathrm{Da}$ are presented by a dexiotropic triple helix while the molecules with lower molecular mass have a conformation of a triple helix with some single chains observed among them. Molecular mass of triple chains is $5 \cdot 10^{3} \mathrm{Da}$, which proves the dependence of the ability to inhibit tumours on the size of a triple helix molecule [17].

However, the induction of synthesis of $\gamma$-interferon and colony-stimulating factor does not depend on the molecule structure and is specific for $\alpha$-configuration of the molecules. It deopends on the presence of $\alpha-(1 \rightarrow 3)$-glycosidic bond in carbohydrate chain rather than on the molecule tertiary structure. Contrary to $\beta$ - $(1 \rightarrow 3)$-glycans, therapeutic features of which are revealed in the range of 500-2000 kDa, no dependence on the molecular mass was observed for $\alpha-(1 \rightarrow 3)$-glu- curonoxylomannane, isolated from jelly mushrooms [19]. Acid glucuronoxylomannane, obtained from fruit bodies of Tremella fuciformis, has three-dimensional structure of the main chain as a left-hand spiral [20]. For instance, Gao et alt. revealed that all the fractions with molecular mass from 1 to $53 \mathrm{kDa}$, extracted via acid hydrolysis from fruit bodies of T. fuciformis, induce the synthesis of interleukin-6 (IL-6) similarly to non-hydrolized fractions [21]. Cultural liquid of T. mesenterica was used to obtain the polysaccharide, the main chain of which is glycosided by xylose and glucoronic acid and presented via $\alpha-(1 \rightarrow 3)$-linked D-manose [22].

Mushroom polysaccharides are composed of both homopolysaccharides, mainly extracted in water, and heteropolysaccharides, containing xylose, mannose, galactose, and uronic acids. They are isolated from water solution using salt precipitation and leaching [23].

Besides antitumour and immunostimulating activity, inherent to some types of glycans, there are polysaccharides with a wide spectrum of other biological features. Inonotus genus, I.obliquus in particular, is a well-known producer of substances with various curative features. Biologically active glycoproteins, isolated from fruit bodies, sclerotium and mycelium of $I$. obliquus, were used as a basis for development of Bifungin preparation, for both treatment and health improvement in general $[24,25]$.

Another species of this genus, I. levis, produces a considerable amount of exopolysaccharides with different pharmacological features [25]. The analysis of monosaccharide composition of polysaccharides, obtained from the cultural liquid, showed that they contain fucose, xylose, galactose, mannose, glucose, and methyl galactose. Anion-exchange chromatography demonstrated that the extract contains two polysaccharides galactan and mannane. The molecular mass of galactan is about $5 \mathrm{kDa}$, and mannane - over $15 \mathrm{kDa}$, respectively. In a main part of the molecule, galactan is a linear chain of $(1 \rightarrow 6)$-linked $\beta$-galactopiranose residues of galactose, irregularly methylated in the third position of the oxygen atom. According to the chemical structure, mannane is an $\beta$ - $(1 \rightarrow 6)$-linked mannopiranose in the main chain and an $\beta$ - $(1 \rightarrow 2)$-mannopiranose - in the side chains. Neither proteins nor lipids were revealed in the polysaccharide [26]. 
Water extraction allowed obtaining polysaccharide preparation KS-2 from mycelium of $L$. edodes. According to its chemical nature this preparation is an $\beta$-glycoprotein, containing such amino acids as serine, threonine, alanine, and proline. Aqueous extracts from mycelium and cultural liquid contain polysaccharides with glucose, galactose, xylose, arabinose, mannose, and fructose. The preparations, obtained from mycelium, are also composed of derivatives of nucleic acids, vitamins of group B, and ergosterol [27].

Glycoprotein K (PSK), containing 62\% of polysaccharide and $38 \%$ of protein, was extracted from T. (Coriolus) versicolor $[19,28]$. Polysaccharide PSK is presented by $\beta$-(1-3), (1-4)-glycan, side chains of which are linked to the main one via $\beta-(1-3)-$ link. The polysaccharide part is composed of glucose and an insignificant amount of galactose, mannose, xylose, and fucose. The protein part of the molecule is rich in asparagine and glutamic amino acids, valine, and leucin. Polysaccharide and protein parts are connected via O-glycosidic linkage between the serine or threonine residues of the protein and $\mathrm{OH}$-groups of carbohydrates, and via $\mathrm{N}$-glucosidic linkage - between asparagine acid and $\mathrm{OH}$-groups of glucose. The molecular mass of polysaccharide is 94-100 kDa. The preparation has considerable biological value as an inhibitor of some human tumours [13, 27, 28].

Besides PSK (krestin), glycoprotein PSP was also obtained from $T$. versicolor (first obtained from COU-1 strain). A chemical structure of PSP differs from that of PSK. A qualitative analysis revealed that it contained arabinose and ramnose along with fucose. The polysaccharide chain is presented by $\beta$-glycan, in which glucose molecules are linked via (1-4)-, (1-3)-, and (1-2)-glycoside linkage. Its molecular mass is about $100 \mathrm{kDa}$ [27].

It means that functionally active glycopolymers, produced by Basidiomycetes, mainly belong to glycans of different structure and glycoproteins. They have similar impact on human organism and its defensive systems. The primary structure of glycans is unlike to be the most decisive factor of their biological activity; more important is a formation of higher conformational structures, which determine biological features of the glycopolymers.
The data on biological activity of products, obtained from Basidiomycetes mushrooms, are summarized in Table.

Types of biological activity of glycans. Antitumour activity of glycans. Antitumour activity of Basidiomycetes mushrooms was first demonstrated by the authors of [25], who tested extracts from fruit bodies of Boletus edulis and other Homobasidiomycetes species while treating mice with Sarcoma 180 [29]. In 1958 calvacin was extracted from fruit bodies of $C$. gigantean, widely used in folk medicine. This preparation was tested as an antitumour medicine in laboratory conditions using different models. In the culture of HeLa cells it demonstrated an inhibiting activity against many types of experimental tumours: Sarcoma 180, breast adenocarcinoma 755, leukemia L-1210 [27]. More than 7000 cultures were checked in the study of extracts from Basidiomycetes mushrooms, which allowed obtaining preparations active against Ehrlich carcinoma, Sarcoma 180, breast cancer, and leukemia $[3,5,11]$.

Therefore, the investigation of higher mushrooms as antitumour means allowed revealing antitumour activity of about 650 Basidiomycetes species, in particular, Auriculariales, Tremellales, and Polyporales orders, Gasteromycetideae and Agaricomycetideae genera, etc.

Clinical research proved the most active tumour inhibitors to be lentinan, extracted from $L$. edodes, D-fractions from Grifola frondosa, schizophyllan (SPG) from S. commune, krestin and glycoprotein PSP from $T$. versicolor. Lentinan, schizophyllan and PSK are currently used in Japan as official preparations in tumour treatment. Their chemical structure is $\beta$-D-glucans ( $\beta$-D-glycoproteins).

Mushroom-produced polysaccharides do not destroy tumour cells directly. Their antitumour effect is determined by activation of the host's immune system. The mentioned substances do not hurt an organism, rather they help it adapt to the changes in environment and stresses, by supporting its main systems, in particular, nervous, hormonal and immune ones [27].

Mechanism of antitumour and immunomodulating action. Antitumour activity of mushroom polysaccharides is based on activation of the thymus-depending mechanism of immune response. It 
Biological activity of products of Basidiomycetes mushrooms metabolism

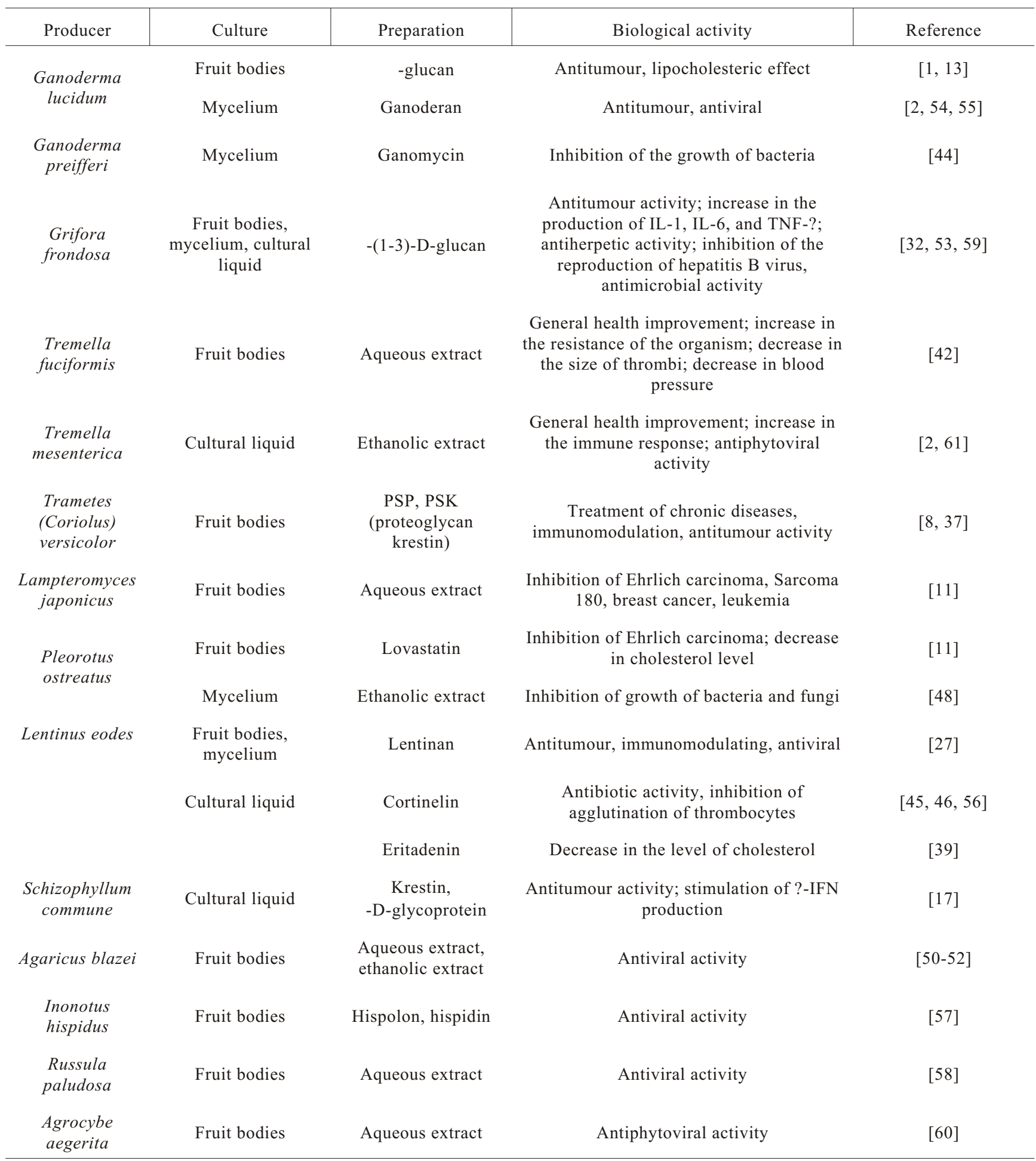

is proven by the inhibition of anticarcinogenic action of lentinan and other polysaccharides in the presence of inhibitors of macrophages. Therefore, after specific recognition of tumor cells, the polysaccharides directly influence the predecessors of T-cells and the intensity of cytokine synthesis by macrophages. Mushroom 
glycans are also known as stimulators of synthesis of natural killers, E-cells, B-cells, and immune-dependent macrophages.

For instance, in an organism with tumour, lentinan is capable of restoring the activity of T-cells to the normal state, which results in complete activation of humoral immunity [30]. This polysaccharide is revealed to induce the high-rate transport of neutrophils, eosinophils, and granulocytes to the target, and to intensify the secretory features of active oxygen and the cytokines production by macrophages. Besides, lentinan increases the macrophages cytotoxicity to metastases, stimulates normal and alternative ways of the complement system, and promotes splitting of $\mathrm{C} 3$ to $\mathrm{C} 3 \mathrm{a}$ and $\mathrm{C} 3 \mathrm{~b}$, thus improving the functionality of macrophages [30]. The impact of lentinan on the activity of macrophages results in the increase of the amount of such substances as a factor of acute-phase proteins induction, a factor of interleukin 1 and IL-3 induction, and a colony-stimulating factor in blood Lentinan induces the activity of various types of antitumour effector cells, in particular, T-killers, natural killers, cytotoxic macrophages, which may have an impact on target cells. Lentinan was shown to increase the sensitivity of thymocytes to IL-2 and susceptibility of normal killers to activation factor and IL-2 [18].

The ability of receptor of complement type 3 three (CR3, also known as Mac-1, CD11b/CD18 or as $\alpha_{M} \beta_{2}$-integrin) to recognize $\mathrm{B}$-glucans allowed the authors of [31] to suppose that it is the main $\beta$-glucan receptor on leucocytes which conditions all immunomodulating effects of these carbohydrates. When phagocytes CR3 are linked to $\mathrm{iC} 3 \mathrm{~b}$ on the membrane of bacteria or yeasts, it triggers the launch of phagocytosis or cytotoxic degranulation, as there is simultaneous recognition of $\mathrm{iC} 3 \mathrm{~b}$ via the site of binding I-domain of CD11b, and specific microbe polysaccharides - via the lectin site, located at $\mathrm{COOH}$-end of I-domain. However, when phagocytes or natural killers (NK) CR3 are linked to $\mathrm{iC} 3 \mathrm{~b}$ on erythrocytes or tumour cells, decreasing the number of CR3-sites for polysaccharides binding to the membrane, neither lysis of cells nor cytotoxic effects are observed.

Cytotoxicity of neutrophils, macrophages and CR3 receptors of NK cells for tumour tissue is achieved through a primary contact of lymphocytes with $\beta$-glucans which inhibits natural resistance of tumour cells [31]. The activation of cytotoxicity of natural killers of CR3 under the impact of $\beta$-glucan in the organism with iC3b-opsonised tumours is accompanied by secretion of the factor of $\alpha$ tumour necrosis (TNF- $\alpha)$, interferon $\alpha$ (IFN- $\alpha)$, IFN- $\gamma$ and IL-6 [31]. Besides, it was revealed that binding of the ligand, located on the surface of tumour cells, to $\beta$-glucan receptor stimulates the activation of a nucleus factor $\mathrm{\kappa B}(\mathrm{NF}-\mathrm{\kappa B})$ in myelogenous cells of human leukemia U-937 [31].

Many mushroom and yeast glycans are capable of stimulating the system of mononuclear phagocytosis (macrophages, monocytes) and some lymphocytes (NK) for the production of interferons and interleukins, i.e. the system, which belongs to the first level of cell protection. Detection of infected or transformed cells provides complete humoral and cell immune response. For instance, treatment of mononuclear cells of peripheral blood with aqueous extract of fruit bodies of $L$. edodes results in higher level of TNF- $\alpha$, IL- $1 \beta$, IL-10 and IL-12 [30].

$\beta-(1-3)-D-g l u c a n$, extracted from $G$. frondosa, increases the production of IL-1, IL- 6 , and TNF- $\alpha$ in the culture of cells of marcophages RAW 264.7. $\mathrm{D}$-fraction of $\beta$-glucan brings up significant increase in the expression of TNF- $\alpha$ by normal killers, IL-12 - by macrophages, $\gamma$-IFN - by T-cells, $\gamma$-IFN, IL- $12 \gamma 70$ and IL-18 - by cells of pancreas and lymph nodes [32].

Schizophyllan, isolated from the cultural liquid of $S$. commune, stimulates the production of $\gamma$-IFN and IL- 8 in the culture of PBMC cells. When modified to one-chain conformation, schizophyllan induces the formation of TNF- $\alpha$ and IL-8 in the culture of cells of human monocytes U-937 and TNF- $\alpha$ - in PBMC [17].

An aqueous extract of PSP has significant impact on the increase in the production of IL- 1 and IL- 6 and decrease in the synthesis of IL-8 in the culture of human promyelocytes HL-60. For instance, the introduction of this preparation in mice triples T-lymphocytes concentration. PSP also induces the IFN synthesis with remarkably higher intensity for $\alpha$-IFN than $\gamma$-IFN. PSK stimulates the formation of IL-1 in PBMC culture much more efficiently than that of TNF [31]. A higher amount of IL-1 is accumulated in 
cells rather than in the nutrient medium, while IL-1 is located in both cultural liquid and cells. In the organism with a tumour, lentinan is capable of restoring the activity of T-cells to the normal level, which results in complete activation of the humoral immunity [30]. PSK is notable for a similar effect [19]. Immunomodulating activity of these polysaccharides may be related to their impact on the hormonal factors which participate in tumour development, and this activity is considerably inhibited with the introduction of thyroxin or hydrocortisone.

Polysaccharides are capable of restoring tumour-specific antigen-dependent hypersensitivity of the organism [33]. PSP introduction in mice with Sarcoma 180 results in significant improvement of the general state. It was revealed that this preparation prevents thymus atrophy and increases the amount of hemolysin, IgG and C3 complement.

Extract of G. lucidum mycelium, injected into mice with T-lymphoma, considerably inhibits tumour growth and prolongs life of the infected animals [34]. The investigation on purified polysaccharides, obtained from mycelium and fruit bodies of this mushroom, revealed that their activity is conditioned by the ability to inhibit tumour growth in mice: Ca755 tumour - by $88 \%$, Sarcoma 180 - by $71 \%$, T-lymphoma - by $79 \%$ [35]. The experiments on rats demonstrated that the preparations, obtained from fruit bodies and mycelia of G.fondosa [36] and T. versicolor [8], also have inhibiting impact on various types of tumours. A considerable antitumour effect is inherent in the polysaccharide, isolated from fruit bodies, mycelia, and cultural liquid of mushrooms of Tremella genus [37]. The mechanism of antitumour activity is conditioned by the stimulation of immune system.

It was revealed that the preparation increases phagocytosis of intraperitoneal macrophages of mice related to red blood cells of chickens. Besides, the polysaccharide stimulates the activity of red bone marrow, normalizes the level of lymphocytes proliferation, and promotes production of IL-2 in ageing mice to that of young ones. It means that polysaccharides of mushrooms of Tremella genus have immunomodulating and immunorestoring features. It is rather important since similar preparations are capable of restoring the functions of immune system under various kinds of stress and immunodeficiency, in particular, in case of acquired immunodeficiency syndrome (AIDS).

Hypolipidemic activity. An ability to decrease the cholesterol level in blood was found for many mushrooms. It was determined that adding a dry powder of fruit bodies of $P$. ostreatus mushroom to the food of rats decreased cholesterol in their blood serum and liver [38]. While investigating the mechanism of action of this preparation, the inhibition of cholesterol synthesis (including that increased due to the activity of lovastatin - an inhibitor of mevalonic acid synthesis) was revealed as well as the capability of this preparation to adsorb cholesterol molecules and to activate lecithin-cholesterol-acytil-transferase, which accelerates further cholesterol transformation.

On the contrary, the extract from $L$. edodes decreases the concentration of free cholesterol in blood plasma because of acceleration of cholesterol accumulation in liver and its removal from blood circulation [39]. This effect is related to eritadenine, obtained from fruit bodies of the mushroom: it activates the cholesterol break-up and its removal from blood. Eritadenine is known to decrease the level of cholesterol and lipids in the blood of animals. The addition of eritadenine to the food of animals during 7 days results in the decrease in the level of cholesterol by $25 \%$ which is more efficient than a diet. Fruit bodies of Aspergillus tereus were used to isolate mevinolin, an inhibitor of the enzyme, participating in early stages of cholesterol synthesis [37, 40].

Similar results were obtained with a dry powder from fruit bodies of G. lucidum, added to food for animals. A lipo-cholesteric effect was demonstrated, i.e. a decrease in the level of cholesterol in atherogenic lipoproteids [34, 41]. A hypocholesteric effect of G. lucidum was revealed in vitro, ex vivo and on animal models of hamsters and pigs. Its activity is related to the lanosterol derivative, capable of decreasing the synthesis of cholesterol; in particular, it can inhibit the transformation of 24, 25-dehydrolanosterol into cholesterol and indirectly inhibit the activity of 3-hydroxy-3-methylglutaryl-CoA

(HMG-CoA) reductase [41]. This effect of mushrooms allows us to assume a potential of products of mushroom metabolism in prophylactics of atherosclerosis and decreasing of the risk of cardiac diseases. 
Impact on blood pressure. It was observed that besides hypocholesteric effect, the mushrooms metabolites can regulate blood pressure. at both hypertony and hypotony. It is an inherent characteristic of mushrooms of Pleurotus genus, as well as of G. frondosa, L. edodes, Polyporus confluens, and G. lucidum $[2,3,36]$. There are different mechanisms of action of different preparations, isolated from mushrooms. In particular, the extracts from L. edodes inhibit agglutination of thrombocytes, and therefore, have antithrombotic activity. Polysaccharides, isolated from $T$. fuciforms, decrease [size of thrombi and blood viscosity, inhibit adhesion of thrombocytes, and influence positively coagulation characteristics of animals blood [42]. Glycoprotein, obtained from mycelium in the course of deep cultivation of Trametes sp., demonstrated a similar action in experiments in vitro and on animal model [37]. Preparations of Armillriella mellea are able to decrease the heart rate, peripheral and cardiac resistance of vessels [43].

Antibacterial activity. The compounds, obtained from cultural liquid, mycelia, and fruit bodies of mushrooms, are characterized by antiviral, antibacterial, and antifungal activity. Taking into account modern state of chemotherapy, especially the occurrence of pathogen strains, resistant to preparations, this type of activity of mushroom metabolites is of considerable interest for researchers.

Mycelium of Ganoderma preifferi was used to obtain ganomycin, which inhibits the development of methicillin-resistant Staphylococcus aureus and several other microorganisms [44]. The fruit bodies of L. edodes were used to obtain cortinelin, which demonstrated antibiotic activity against Candida albicans, S. aureus, and Bacillus subtilis [45]. In vitro experiments showed that the extracts of mycelium of this mushroom inhibit the growth of phytopathogenic bacteria ( $P$. syringae pv. glycinea, $P$. syringae pv. tabaci, $X$. campestris pv. glycines, Erwinia amylovora, Ralstoma solanacearum, Cflaccumfaciens pv. flaccumfaciens) and causative agents, affecting foodstuffs and humans (B. cereus, Escherichia coli, Listeria monocytogenes, Sa monella typhimurium, $S$. aureus) [8, 46]. While adding the extract of this mushroom mycelium to the medium with sprouts of tomatoes and haricot, it was demonstrated that contrary to control plants the experimental ones had no symptoms of bacterial rot [46], caused by $R$. solanacearum or Curtobacterium flaccumfaciens pv. Flaccumfaciens. No signs of the disease were observed during 40 days. These results indicate a possible presence of antibiotic substances in mushroom mycelium.

The investigation on antibacterial and antifungal features of extracts of mycelium and filtrates of the cultural liquid of different strains of $L$. edodes proves their capability of inhibiting growth of gram-positive and gram-negative bacteria, yeasts, and filamentous mushrooms. [The] Mushroom activity is strain-specific.

The elaborated preparations had inhibiting impact on B. subtilis, B. cereus subsp. mycoides, C. albicans, and $A$. niger, and the addition of ethanolic extracts to the nutrient medium with grown bacteria and mushrooms resulted in inhibition of $T$. harzianum development. The active components of the mentioned preparations were lentinamycin and eritadenine, the former having higher antibiotic activity [47].

The substances, extracted from fruit bodies of L. edodes, had antibacterial features regarding C. albicans. Their addition to the nutrient medium for cultivation of microorganisms resulted in significant decrease of the number of colony-forming units of E. coli O-114, S. aureus, and St. faecalis [34]. Lentinan also inhibits the development of Mycobacterium tuberculosis and Listeria monocytogenes [30].

The products, obtained from the mycelium of P. ostreatus (Jacq.:Fr) Kumm, decreased the growth of A. niger and mold [48].

Polysaccharide PSK from T. versicolor inhibited the growth of $C$. albicans, and in the in vivo experiments krestin increased considerably the resistance of mice to such microorganisms as Pseudomonas aeruginosa, S. aureus, C. albicans, Klebsiella pneumoniae, M. leprae, L. monocytogenes, Serratia marcescens, St. pneumoniae, Bacteroides fragilis, Cryptococcus neoformans, and Aspergillus fumigatus [8]. The mechanism of antimicrobial action is based on the activation of bactericidal features of polymorphonuclears as well as on the induction of antimicrobial cytokines (necrosis factor of tumours and IL-1). A similar effect was revealed for aqueous 
extracts from fruit bodies of G. frondosa and Lepista nuda. It was observed that the symptoms of chronic yeast infection of women were significantly milder after everyday use of the preparations [49].

Antiviral activity. Polysaccharides, produced by Basidiomycetes mushrooms, are capable of inhibiting the development of viral infections. This type of activity was observed for many mushrooms species. The mechanism of antiviral effect may consist in hindering the adsorption of a viral part on the cell, in blocking viral enzymes and synthesis of nucleic acids of viruses, as well as in improving organism immunity. As of today the main investigations have been conducted on the model of viruses, known as causative agents of opportunistic infections in patients with AIDS and pathogens, widely spread among both humans and animals.

For instance, the aqueous extract of $A$. blazei inhibits the development of the human herpes simplex virus, type 1 (HSV-1) and ovine herpes virus. This preparation in concentrations of 50 and $100 \mu \mathrm{g} / \mathrm{ml}$ inhibits pathogen development in the cell by $78 \%$. Inhibition was higher if the virus was pretreated with the preparation prior to before infecting cells, i.e. the substance had higher viricidal activity, which evidences to its impact on surface proteins of the virus and to adsorption of the latter on the cell. Besides, this preparation also demonstrated therapeutic activity, which testifies to its participation in inhibition of virus replication at later stages [50].

The aqueous and ethanolic extracts of $A$. blazei inhibit cytopathic action of the Western equine encephalitis virus (WEEV) and HSV in the culture of Vero cells, the ethanolic extract having higher activity [51]. The mentioned polysaccharide preparations inhibit the development of [the] poliovirus, type 1, in the culture of Hep- 2 cells. The investigated substances were found to be active while treating the cells after their infecting with the virus, but they had no virucidal effect, i.e. they inhibited early stages of virus replication rather than influenced virus adsorption [52].

An antiherpetic activity was revealed for the protein, isolated from fruit bodies of G. frondosa. This preparation inhibited virus replication in vitro and significantly decreased the pathogen production when used locally [53]. The products, obtained from the mycelium of G. lucidum, inhibit the development of $\mathrm{HSV}$ in the cell culture. The mechanism of their action consists in hindering virus adsorption on the cell due to blocking both cell and viral receptors [54]. Treatment of patients with chicken pox, using the aqueous extract from fruit bodies of G. lucidum, moderated the clinical course and shortened the disease duration [55].

Water soluble compounds, obtained from the mycelium of L. edodes (jLs and jLs-18 strains), demonstrated antiviral and immunomodulating properties. The antiviral effect is based on inhibition of virions maturing in cells, which was revealed on the HSV model [27] both in vitro and in vivo. Besides, lentinan demonstrates antiviral activity against vesicular stomatitis virus, encephalitis, Abelson virus, adenovirus, type 12 , stimulates resistance of mice to respiratory infection and influenza virus, type A [27]. This preparation also inhibits the development of the human immunodeficiency virus. The chemotherapy of human T-lymphocytes culture with azidotymidine either alone or in combination with lentinan, showed that the combined prepation reduced the percentage of infected T-cells more effectively than azidotymidine alone. The mechanism of action of lentinan and its sulphated derivatives, which also showed antiviral activity, consists in inhibition of HIV replication and prevention of virion adsorption on cells [56].

The ethanolic extracts of $I$. hispidus fruit bodies, hispolon and hispidin, demonstrated antiviral activity regarding influenza types $\mathrm{A}$ and $\mathrm{B}$ in the culture of chicken embryos [57]. The aqueous extract of Russula paludosa in the concentration of $1 \mathrm{mg} / \mathrm{ml}$ inhibited the activity of HIV-1 by $97.6 \%$ [58]. The preparations, obtained from the cultural liquid of $L$. edodes by either sedimentation with ethanol or extraction inhibit HIV development in the culture of MT-4 cells, the first procedure providing lower activity. It was demonstrated that these preparations block the primary stage of virus reproduction [56]. D-fraction, obtained from $G$. fondosa, decreased the reproduction of hepatitis B virus. Its usage in combination with interferon results in considerably higher activity of both substances, i.e. D-fraction has synergic effect regarding IFN activity, which makes the complex preparation promising in treatment of chronic hepatitis B [59]. 
Therefore, numerous investigations proved that polysaccharides and glycoproteins of Basidiomycetes mushrooms are capable of inhibiting the activity of viruses of humans and animals. It has been demonstrated only recently that these preparations may inhibit viruses of plants [60]. For instance, lectin, isolated from fruit bodies of Agrocybe aegerita by water extraction, delays the development of TMV-infection in plants of Nicotiana glutinosa. Lectin in the concentrations of $50 \mu \mathrm{g} / \mathrm{ml}$ and $200 \mu \mathrm{g} / \mathrm{ml}$ provided $62.5 \%$ and $84.3 \%$ inhibition of necrosis, respectively. The mechanism of antiviral action consists in prevention of infecting plant cells due to lectin attachment]to their viral parts.

The investigation on antiphytoviral features of polysaccharide of glucuronoxylomannane (GXM), isolated from the cultural liquid of $T$. mesenterica, demonstrated that this glycan inhibited TMV-infection of tobacco and datura plants [61]. The polysaccharide added to virus suspension had lower activity than that introduced into the intercellular space of a leaf.

The results presented testify to the fact that GXM influences the virus prior to its infection as well as the processes in a cell. In particular, the polysaccharide may inhibit the virus reproduction and induce the resistance of plants de novo, which is proven by sensitivity of this activity to the inhibitor of RNA transcription on DNA matrix of actinomycin D [62].

Antiallergenic activity. There are some mushroom extracts inhibiting the activity of immune system, which may be used in allergy treatment. An introduction of dry ethanolic extracts of fruit bodies of Hypsizygus marmoreus, Flammulina velutipes, Philiota nameko, and P. eryngii into the food for mice resulted in disappearance of allergy symptoms [63]. The antiallergenic activity was also revealed for several components of G. lucidum. For instance, ganoderic acid $\mathrm{C}$ and $\mathrm{D}$ slow down the histamine discharge by mast cells of rats. $T$. populinum mushrooms, used as a food additive, causes the regression of allergic reaction in patients with nettle rash [2].

Conclusions. The analysis of literature data demonstrates that the structural components and extra-cellular products of Basidiomycetes mushrooms metabolism, in particular, carbohydrate biopolymers, are currently under active investigation. As their curative features have long been known, this stage consists in scientific justification of this activity and study on the influence spectrum of glycans. In particular, numerous works are dedicated to the study on immunomodulating and antitumour properties.

It was revealed that the level and type of polysaccharides activity depend on the producer and the macromolecule structure. For instance, antitumour features are inherent in $\beta$-D-glucans with prevailing $\beta-(1 \rightarrow 3)-$ links, while the induction of [IFN] synthesis is attributed to $\alpha$-molecules. Besides, the glucans activity is determined by the degree of molecule branching, tertiary structure, water solubility, molecule charge, etc.

The polysaccharides, produced by Basidiomycetes mushrooms, are characterized by antibiotic features and the ability to inhibit the development of viral infections. The mechanisms of glycans action on bacteria and viruses differ; they may consist either in the stimulation of immune response of the organism or in direct action on the pathogen. Glycans block the adsorption processes of pathogens, inhibit their reproduction in the cell and activate natural mechanisms of cell protection. The study on antiviral and antibacterial features of polysaccharides is of great importance due to the appearance of new strains of microorganisms, resistant to modern preparations.

Up to date, a significant number of preparations have been developed mainly as food additives and are widely used to improve the general health. Besides, there are current clinical investigations of the preparations based on mushroom polysaccharides, which are elaborated as additional means in the therapy of oncological diseases, HIV-infection, hepatitis B and $\mathrm{C}$ viruses, herpes viruses, etc. The patients, who took the mentioned substances along with chemotherapy, had better general condition and life quality compared to those who did not take mushroom polysaccharides. In Japan these preparations are used as official medicine for general health improvement, prophylactics of malignant tumours, therapy of oncological diseases, and prevention of metastases.

Therefore, Basidiomycetes mushrooms are a source of substances with various medical and biological features. The preparations on their basis are non-toxic 
and increases considerably the degree of patients' survival. Further investigations on these substances open new perspectives in the search for medical means to treat currently incurable diseases and to improve the organism functioning.

\section{О. М. Поліщук, О. Г. Коваленко}

Біологічна активність глікополімерів базидіальних грибів

Резюме

Проаналізовано літературні дані щзодо біологічної активності глікополімерів, одержаних з культуральної рідини, плодових тіл і міцелію базидіальних грибів. Розглянуто структуру та властивості полісахаридів грибів, а також залежність функиіонально-біологічної активності від фізико-хімічних характеристик макромолекул. Обговорюються можливості застосування препаратів, отриманих на основі згаданих полісахаридів, для захисту рослин, а також для лікування й профілактики захворювань людини і тварин.

Ключові слова: Basidiomycetes, грибні полісахариди, структура гліканів базидіомічетів, хімічні і біологічні властивості гліканів базидіоміцетів.

\section{Е. Н. Полищук, А. Г. Коваленко}

Биологическая активность гликополимеров базидиальных грибов

Резюме

Проанализированы литературные данные о биологической активности гликополимеров, выделенных из культуральной среды, плодовых тел и мииелия базидиальных грибов. Рассмотрены структура и свойства полисахаридов грибов, а также зависимость функиионально-биологической активности от физико-химических характеристик макромолекул. Обсуждается возможность использования препаратов, полученных на основе указанных полисахаридов, для лечения и профилактики заболеваний человека и животных, а также для защиты растений от патогенов.

Ключевые слова: Basidiomycetes, грибные полисахариды, структура гликанов базидиомицетов, химические и биологические свойства гликанов базидиомицетов.

\section{REFERENCES}

1. Wasser S. P. Reishi or Ling Zhi (Ganoderma lucidum) // Encyclopedia of Dietary Suppl.-Boston, 2005.-P. 603-622.

2. Lindeguist U., Niedermeyer T. H., Julich $W$. The pharmacological potential of mashrooms // eCAM.-2005.-2, N 3.P. 285-299.

3. Wasser S. P., Didukh M. Ya. Mushroom polysaccharides in human health care // Biodiversity of fungi. Their role in human life / Ed. M. K. Rai.-New York, 2005.-P. 289-328.
4. Ooi V. E. C. Medicinally important fungi// Science and Cultivation of Edible Fungi.-2000.-1.-P. 41-51.

5. Chinara G., Maeda Y. Y., Hamuro J. Current status and perspectives of immunomodulators of microbial origin // Int. J. Tissue Reactions.-1982.-4.-P. 207-225.

6. Wasser S. P. Medicinal mushrooms as a source of antitumor and immunomodulating polysaccharides // Appl. Microbiol. and Biotechnol.-2002.-60, N 3.-P. 258-274.

7. Ikekawa T., Uehara N., Maeda Y., Nakanishi M., Fukuoka F. Antitumor activity of aqueous extracts of edible mushrooms // Cancer Res.-1969.-29, N 3.-P. 734-735.

8. Hiroshi S., Takeda M. Diverse biological activity of PSK (Krestin), a protein-bound polysaccharide from Coriolus versicolor (Fr.) Quel. // Mushroom biology and mushroom products.-Hong Kong: Chin. Univ. press, 1993.-P. 237-245.

9. Marchessalt R. H., Deslandes Y., Ogawa K., Sundarajan P. $R$. X-ray diffraction data for $\beta$-D-glucan // Can. J. Chem.1977.-55, N 2.-P. 300-303.

10. Gorin P. A., Barreto-Berger E. The chemistry of polysaccharides of fungi and lichens // The Polysaccharides.-1983.2.-P. 365-409.

11. Zaidman B.-Z., Yassin M., Mahajna J., Wasser S. P. Medicinal mushroom modulators of molecular targets as cancer therapeutics // Appl. Microbiol. and Biotechnol.-2005.-67, N 4.- P. 453-468.

12. Mizuno T. A. Development of antitumor polysaccharides from mushroom fungi // Foods and Food Ingred. J. Jap.1996.-167.-P. 69-85.

13. Mizuno T., Saito H., Nishitoba T., Kawagashi H. Antitumoractive substances from mushrooms // Food Rev. Int.-1995.11.-P. 23-61.

14. Mizuno T. The extraction and development of antitumor-active polysaccharides from medicinal mushrooms in Japan (Review) // Int. J. Med. Mushr.-1999.-1.-P. 9-29.

15. Ovodov Yu. S. Polisacharidy gribov, mchov i lishaynikov, struktura i fiziologicheskaya aktivnost' // Tr. Komi nauch. zentra UrO RAN.-1997.-N 156.-12 c. (in russian).

16. Maeda Y. Y., Watanabe S. T., Chihara C., Rokutanda M. Denaturation and renaturation of a $\beta-1,6 ; 1,3$-glucan, lentinan associated with expression of T-cell-mediated responses // Cancer Res.-1988.-48, N 3.-P. 671-675.

17. Yanaki T., Ito $W$., Tabata K. Correlation between the antitumor activity of a polysaccharide schizophyllan and its triplehelical conformation in dilute aqueous solution // Biophys. Chem.-1983.-17, N 4.-P. 337-342.

18. Puchkova T. A. Glubinnyy mizeliy griba Lentinus edodes: sostav i biologicheskaya aktivnost': Materialy yubileynoy konf., posvyaschennoy 85-letiyu kafedry mikologii i al'gologii MGU im. M. V. Lomonosova // Mikologiya i al'golo giya.-M., 2004.-C. 108.

19. Ooi V. E., Liu F. A review of pharmacological activities of mushroom polysaccharides // Int. J. Med. Mushr.-1999.-1.P. 195-206.

20. Yui T., Ogawa K., Kakuta M., Misaki A. Chain conformation of a glucuronoxylomannan isolated from fruit body of Tremella fuciformis Berk // J. Carbohydrate Chem.-1995.-14, N 2.-P. 255-263.

21. Gao Q.-P., Jiang R.-Z., Hui-qun C., Einar J., Rolf S. Characterization and cytokine stimulating activities of heteroglycans from Tremella fuciformis // Planta Med.-1996.-62.P. 297-302.

22. Vinogradov E., Petersen B. O., Duus J. O., Wasser S. P. The isolation, structure and applications of the exocellular 
heteropolysaccharide glucuronoxylomannan produced by Yellow Brain Mushroom Tremella mesenterica Ritz.:Fr. (Heterobasidiomycetes) // Int. J. Med. Mushr.-2004.-6, N 4.-P. 335-345.

23. Boldizsar I., Horvath K., Szedlay G., Molnar-Perl I. Simultaneous GC-MS quantitation of acids and sugars in the hydrolyzates of immunostimulants, water soluble polysaccharides of Basidiomycetes // Chromatographia (Germany).-1998.-47, N 7-8.-P. 413-419.

24. Mizuno T., Zhuang C., Abe K., Okamoto H., Kiho T., Ukai S., Leclerc S., Meijer L. Antitumor and hypoglycemic activities of polysaccharides from the sclerotia and mycelia of Inonotus obliquus (Pers.: Fr.) Pil. (Aphyllophoromycetideae) // Int. J. Med. Mushr.-1999.-1.-P. 301-316.

25. Zjawiony J. K. Biologically active compounds from Aphyllophorales (polypore) fungi // J. Nat. Product.-2004.- 67, N 2.-P. 300-310.

26. Vinogradov E., Wasser $S$. P. The structure of a polysaccharide isolated from Inonotus levis $\mathrm{P}$. Karst. mushroom (Heterobasidiomycetes) // Carbohydrate Res.-2005.-340, N 18.P. 2821-2825.

27. Wasser S. P., Weis A. L. Medicinal properties of substances occurring in higher Basidiomycetes mushrooms: current perspectives // Int. J. Med. Mushr.-1999.-1, N 1.-P. 31- 62.

28. Rai M., Tidke G., Wasser S. P. Therapeutic potential of mushrooms // Nat. Prod. Radiance.-2005.-4, N 4.-P. 246-257.

29. Lucas E. N., Montesano R., Pepper M. S., Hafner M., Sablon $E$. Tumor inhibitors in Boletus edulis and other holobasidiomycetes // Antibiotics Chemother.-1957.-4.-P. 1-4.

30. Chihara $G$. Immunopharmacology of lentinan, a polysaccharide isolated from Lentinus edodes. Its application as a host defense potentiator // Int. J. Orient. Med.-1992.-17.-P. 5577.

31. Ross G. D., Vetvicka V., Yan J., Xia Y., Vetvickova J. Therapeutic intervention with complement and beta-glucan in cancer // Immunopharmacology.-1999.-42, N 1-3.-P. 61-74.

32. Kodama N., Komuta K., Nanba H. Effects of D-fraction, a polysaccharide from Grifola frondosa on tumor growth involve activation of NK cells // Biol. Pharm. Bull.-2002.-25, N 12.P. 1647-1650.

33. Aoki T. Immune modulation agents and their mechanisms // Immunol. Stud.-1984.-25.-P. 62-77.

34. Uspechi medizinskoy mikologii / Pod red. Yu. V. Sergeeva.M., 2001.-T. 1.-358 s.(in russian).

35. Avtonomova A. V., Belizkiy I. V., Isakova E. B., Evsenko M. S., Sedakova L. A., Usov A. I., Treschalina E. M., Tichonov V. P., Buchman V. M., Krasnopol'skaya L. M. Vodorastvorimye polisacharidi mizeliya Ganoderma lucidum: biotechnologiya polucheniya i protivoopucholevye svoystva // Materialy 4-go Vseros. kongr. po med. mikologii.-M., 2006.-S. 217-219 (in russian).

36. Mizuno T. «Antitumor mushrooms» - Ganoderma lucidum, Grifola frondosa, Lentinus edodes and Agaricus blazei.-Tokyo: Gendai-shorin, 1997.-188 p.

37. Danilyak M. I., Reshetnikov S. V. Likars'ki gribi. Medichne zastosuvannya ta problemi biotechnologii.-K., 1996.- $58 \mathrm{~s}$. (in russian).

38. Gunde-Cimerman N. Medicinal value of the genus Pleorotus (Fr.) P. Krast. (Agaricales S. R., Basidiomycetes) // Int. J. Med. Mushr.-1999.-1.-P. 69-80.

39. Suzuki S., Oshima S. Influence of Shiitake, Lentinus edodes, on human serum cholesterol // Ann. Rep. Nat. Inst. Nutr.1974.-25.-P. 89-94.
40. Vincent E. C., Ooi V. E., Liu F. Immunomodulation and anticancer activity of polysaccharide-protein complexes //Curr. Med. Chem.-2000.-7.-P. 715-729.

41. Berger A., Rein D., Kratky E., Monnard I., Hajjaj H., Meirim I., Piguet-Welsch C., Hauser J., Mace K., Niederberger P. Cholesterol-lowering properties of Ganoderma lucidum in vitro, ex vivo and in hamsters and minipigs // Lipids Health Dis.-2004.-3, N 2.-P. 3-20.

42. Sheng J., Chem Q. Effect of polysaccharides from Auricularia auricular, Tremella fuciformis spores on experimental thrombus formation // Zhongguo Yaoke Daxue Xuebao.1990.-21.-P. 39-42.

43. Chang H. M., But H. P. P. Pharmacology and applications of chinese materia medica.-Singapore: World Scientific, 1986.-740 p.

44. Mothana R. A., Jansen R., Julich W. D. Ganomycin A and B, new antimicrobial farnesyl hydroguinones from the basidiomycete Ganoderma prefferi // J. Nat. Prod.-2000.-63.P. 416-418.

45. Bianco C. Basidiomycetes in relation to antibiosis. Antibiotic activity of mycelia and cultural liquids // Bact. Viral Immunol.-1981.-75.-P. 274-627.

46. Pacumbaba R. P., Caula A. B., Pacumbaba R. O. Shiitake mycelial leachate suppresses growth of some bacterial species and symptoms of bacterial wilt of tomato and lima Bean in vitro // Plant Dis.-1998.-83, N 1.-P. 20-23.

47. Soboleva N. Yu., Krasnopol'skaya L. M., Fedorova G. B., Katrucha G. S. Antibioticheskie svoystva shtamov bazidial'nogo griba Lentinus edodes (Berk.) Sing. // Antibiotiki i chimioterapiya.-2006.-51, N 7.-C. 3-8.

48. Gerasimenya V. P., Efremenkova $O$. V., Kamzolkina $O$. V., Bogus T. A., Tolstych I. V., Zenkova V. A. Antimicrobial and antitoxic action of Pleurotus ostreatus (Jacq.:Fr.) Kumm. extracts // Int. J. Med. Mushr.-2002.-4, N 2.-P. 127-132.

49. Altshul $S$. Mushroom remedy for chronic yeast infections // Prevention Magazine.-2001.-1.-P. 53-60.

50. Bruggemann R., Orlandi J. M., Benati F. J. Antiviral activity of Agaricus blazei Murrill ss. Heinem extract against human and bovine herpes viruses in cell culture // Braz. J. Microbiol.-2006.-37, N 4. P. 45-51.

51. Sorimachi K., Ikehara Y., Maezato G., Okubo A., Yamazaki S., Akimoto K., Niwa A. Inhibition by Agaricus blazei Murill fractions of cytopathic effect induced by Western Equine Encephalitis (WEE) virus on VERO cells in vitro // Biosci., Biotechnol. and Biochem.-2001.-65, N 7.-P. 1645-1647.

52. Faccin L. C., Benati F., Rincao V. P., Mantovani M. S., Soares S. A., Gonzaga M. L., Nozawa C., Linhares R. E. Antiviral activity of aqueous and ethanol extracts and of an isolated polysaccharide from Agaricus brasiliensis against poliovirus type $1 / /$ Appl. Microbiol.-2007.-45, N 1.-P. 24-28.

53. Gu C. Q., Li J. W., Chao F., Jin M., Wang X. W., Shen Z. $Q$. Isolation, identification and function of a novel anti-HSV-1 protein from Grifola frondosa // Antiviral Res.-2007.-75, N 3.-P. 250-257.

54. Zubing L., Jing L., Yifang Z. Possible mechanism underlying the antiherpetic activity of a proteoglycan isolated from the mycelia of Ganoderma lucidum in vitro // J. Biochem. and Mol. Biol.-2005.-38, N 1.-P. 34-40.

55. Hijikata Y., Yasuhara A., Sahashi Y. Effect of an herbal formula containing Ganoderma lucidum on reduction of herpes zoster pain: a pilot clinical trial // J. Clin. Med.-2005.-33, N 4.-P. 517-523.

56. Tochikura T. S. Inhibition (in vitro)of replication and of the cytopathic effect of human immunodeficiency virus by an 
extract of the culture medium of Lentinus edodes mycelia // Med. Microbiol. Immunol.-1988.-177, N 5.-P. 235-244.

57. Awadh A. N., Mothana R. A., Lesnau A., Pilgrim H., Lindequist $U$. Antiviral activity of Inonotus hispidus // Fitoterapia.-2003.-74, N 5.-P. 483-485.

58. Wang J., Wang H. X., Ng T. B. A peptide with HIV-1 reverse transcriptase inhibitory activity from the medicinal mushroom Russula paludosa // Peptides.-2007.-28, N 3.P. 560-565.

59. Gu C. Q., Li J., Chao F. H. Inhibition of hepatitis B virus by D-fraction from Grifola frondosa: synergistic effect of combination whith interferon-alpha in HepG2 2.2.15 // Antiviral Res.-2006.-72, N 2.-P. 162-165.

60. Hui S., Zhao C. G., Tong X., Qi Y. P. A lectin with mycelia differentiation and antiphytovirus activities from the edible mushroom Agrocybe aegerita // J. Biochem. and Mol. Biol.2003.-36, N 2.-P. 214-222.
61. Kovalenko O. G., Polischuk O. M. Vpliv glyukuronoksilomanu Tremella mesenterica Ritz. Fr. (Basidiomycota) na stiykist' roslin do virusu tyutyunovoï mozaïki // Mikrobiol. Zhurn.-2009.-N 1.-S. 50-56 (in russian).

62. Kovalenko O., PolishchukE. Antiviral activity of glucuronoxylomannan Tremella mesenterica Ritz.Fr. // The Young Scientists and Students Int. Sci. Conf. «Modern Problems of Microbiology and Biotechnology».-Odessa, 2007.-P. 186.

63. Sano M., Yoshino K., Matsuzawa T., Ikekawa T. Inhibitory effect of edible higher basidiomycetes mushroom extracts on mouse type IV allergy // Int. J. Med. Mushr.-2002.-4, N 1.P. 37- 41 . 